\title{
Health Behaviors for Vaginal Infection among Married Women in Ismailia City
}

\author{
Zeinab A. Baraia, Hayat I. Mohamed' Nagat S. Shalaby and Nerminen. El- \\ Maraghy \\ The Department of Obstetric \& Gynecological Nursing, Faculty of Nursing, Suez Canal \\ University; the Department of Maternal \&Newborn Health Nursing, Faculty of Nursing, \\ Cairo University; the Department of Maternity, Obstetric \& Gynecological Nursing, Faculty \\ of Nursing, Port Said University; the Department of Microbiology \& Immunology, Faculty of \\ Medicine, Suez Canal University
}

\begin{abstract}
Background: Vaginal infection is a significant feminine health problem, that is a great burden and associated with substantial discomfort, it is the most frequent problem for gynecologic medical visits.

Aim: This study aimed to evaluate health behaviors that are associated with vaginal infections among married women in Ismailia city.

Materials and Methods: Descriptive study design was conducted in the month of July 2012. Eight governmental rural \& urban PHC centers in Ismailia were randomly selected to representing the geographical zones and flow up rate. A total of (360) married woman at reproductive age was included. Pregnant women, medical disorders such as diabetes \& thyroid disorder, after antibiotic treatment and use of oral contraceptive pills were excluded. Two main tools were used, structured interviewing and vaginal swap for microbiological tests.

Results: The study results revealed that the majority infected woman had unsatisfactory health behavior, with only $17.0 \%$ of them had satisfactory behavior.

Conclusion: Most of the sample got unsatisfactory level of health behaviors and there were high significant association between unsatisfactory health behaviors as personal hygiene, sexual hygiene, menstrual hygiene, vaginal hygienic practices and toileting practices and vaginal infection. Recommendation: Health educational program through different media to women for vaginal proper hygienic care and health behaviors that can be used to promote the prevention of vaginal infection for women throughout their lives.
\end{abstract}




\section{Introduction}

VAGINAL infection is a significant feminine health problem, that is a great burden and associated with substantial discomfort, it is the most frequent problem for gynecologic medical visits (Gooch, 2011 and Johnson, 2010). Most women experience minor vaginal problems from time to time. These problems can be related to menstrual cycles, sex, infection, birth control methods, aging, medicines, or changes after pregnancy. Vaginitis is a common vaginal problem that affects the women quality of life, life style practices, and relationship (American Academy of nurse practitioners (AANP), 2010).

Many researchers reported that the majority of women experience vaginal infection at least once in their life. It can occur in a single episode, or recur throughout a woman's lifetime. Some women will seek medical help, but a lot of them self-treated with over-the-counter medications and this increase the recurrence (American Social Health Association (ASHA), 2013).

Vaginitis is a distressing condition that affects many women at the reproductive age and associated with many substantial discomfort and complications. It is affects the women quality of life, life style practices, and relationship. The nurse as practitioner focus on health promotion, risk reduction and disease prevention through the use of counseling strategies to effectively address the concerns of women, promotes health behaviors, and reduces the risk of potential infections. The early detection of the problem and its causes reduce the financial, physical and medical burden on women and consequently, their families. So, the study was conducted to evaluate the health behaviors that are associated with vaginal infections among married women in Ismailia city.

Infectious vaginitis accounts about $90 \%$ of all cases of vaginal infections at reproductive age women and it's caused by one or more of the following organisms: candida, trichomonas, and Gardnerella. Candidiasis caused by Candida albicans (C. albicans) as a yeast, Bacterial vaginosis (BV) caused by Gardnerella vaginalis (G. vaginalis) as bacteria, and Trichomonas vaginalis (T. vaginalis) caused by protozoa. Moreover, less common types of infections are caused by gonorrhea, Chlamydia, Mycoplasma, Herpes and Campylobacter (Schnatz, 2011).

The primary role of the nurse in managing vaginal infections is health education to modify the health behaviors and to prevent the occurrence as well as recurrence of vaginal infections. The prevention requires changing in the sexual behaviors that put the women at the risk of infection and teach the women the most common symptoms and risk factors for vaginal 
infections, So the nurse's helps the women well by teaching them the precautions in order to avoid vaginal infections or to prevent its recurrence and to improve their reproductive health's (Ricci \& Kyle, 2009).

\section{Aim of the study:}

To evaluate the health behaviors that are associated with vaginal infections among married women in Ismailia city.

\section{Research questions:}

The aim of this study achieved through answering the following questions:

1. What is the prevalence of vaginal infection among married women in Ismailia city?

2. What are most common types of vaginal infection among married women in Ismailia City?

3. What are the health behaviors of married women aggravate vaginal infections?

4. What is the women's compliance level during vaginal infections treatment?

\section{Materials and Methods}

Study Design: Descriptive design was planned on married women.

Setting: Eight governmental rural PHC centers as (Abu- Atwa, Abu- Kalifa, El Mahsama, El Manaif) \& urban PHC centers (El- shikh zaid, El- sabaa banat, El-shohada, Hy El- salam) in Ismailia were randomly selected to representing the geographical zones.

Sample: A total of (360) married women at reproductive age (18-44) was purposively selected and the sample calculated assuming the RTI prevalence of 52.8\% at $95 \%$ level confidence. Pregnant women, medical disorders such as diabetes \& thyroid disorder, after antibiotic treatment and use of OCC pills were excluded.

\section{Data collection tools:}

The data collected from the centers with equal number of woman. Verbal consent was obtained from all women in the study. If any woman refused to participate another one was identified. Two main tools were used, structured interviewing and vaginal swap for microbiological tests. Structured interviewing was pre tested for appropriateness in a $10 \%$ of sample size in the Ismailia health centers, prior to initiating the study. Data collection started after formal consent of the Director of Health Centers, 2012. Information was obtained on health behaviors as personal hygiene, sexual hygiene, menstrual hygiene, vaginal hygienic practices and toileting practices. 
Pilot study: Ten percent (36 women) of the total sample was used as a pilot study. The purpose of the pilot study was to test the applicability, to clarify the feasibility and clarity of the tools and to test the sequence of questions to maintain consistency. Also, served to estimate the time needed to complete the tool, helped to find out any problems that might interfere with data collection, and to determine the appropriate data and time for data collection. According to the results of the pilot study, the necessary modifications in the tool were carried out, and determine the microbiological tests needed. The women in the pilot study were not enrolled in the study.

Ethical considerations: The aim of the study has been explained to directors, doctors, head nurse and staff nurses at PHC centers to gain cooperation before asking women to participate in the study, stressing on confidentiality of the collected information, also oral or written consent was collected. The researcher emphasized that participation were absolutely voluntary and they will informed with the result of microbiology as follow up.

Data analysis: Data enter and analyzed by Statistical Package for Social Sciences (SPSS) version 20. To describe the demographic profile of the married women enrolled in the study, descriptive statistics, including frequency, percent distribution, mean and their standard deviation, were obtained. Non parametric analysis was performed to identify health behaviors associated with vaginal infection.

\section{Results}

The study results demonstrated in the following: Figure (1) showed that, the great majority of the married women had vaginal infection while only $6.4 \%$ of them was haven't infection.

Figure (2) showed the causative organism of vaginal infection, E.coli counted less than onethird of infected women, followed by Klebsilla less than one-quarter of them, S. aureus (18.4\%), and streptococcus (15.4\%). The figure also showed only (11.3\%) of them had Candida infection, $(9.2 \%)$ had G. vaginalis, while $(5.6 \%)$ had proteus and $(3.9 \%)$ had Trichomoniasis.

Personal hygiene of studied women presented in table 1, there were high significance association between personal unhygienic practices and vaginal infection. Also increased prevalence of women doesn't cutting their nails frequently with no significance association. 
Table (2) denoted that, there were high significance association between sexual unhygienic practices and vaginal infection. Most of the married women intercourse in the presence of vaginal infection and only one of them used a condom insignificantly. This table described the vaginal unhygienic practices of studied women; there were significance association between vaginal unhygienic practices and vaginal infection. As regards the vaginal douching with soapy water was found less than three quarters of the infected women douching with saponaceous water and less than one third of them use stiz bath during douching.

Table (4) demonstrated the menstrual hygiene of studied women. There were high significance association between women didn't perform menstrual hygienic practices and vaginal infection. The most of infected women use sanitary pad didn't change it every six hours. As regard changing towels, two fifth of infected women used a cloth towel didn't change it every 2:4 hours. The same table showed that, more than one quarter of infected women didn't shower during menstruation.

Toileting practices presented in table (5), there were high significant relation between toileting practice and vaginal infection. More than two third of infected women didn't wiping the pernium from front to back. All infected woman in the study wiped by bare hands.

Health behaviors illustrated in figure (3) were showed that, most of infected women had unsatisfactory health behaviors. Meanwhile only $17 \%$ of them had satisfactory health behaviors. $X^{2}$ test $\left(0.000^{*}\right)$ with high significant association between unsatisfactory health behaviors and vaginal infection at $p$ value $<0.05$.

Table (6) showed that, there was significant association between previous treatment and vaginal infection. Less than two third of infected women was follow a regimen of treatment. Also there was high significant association between the uses of modalities without medical advice and vaginal infection. Regarding to spouses compliance to treatment, more than one quarter of spouses treated with their wives. More than two third of infected women spouses followed a regimen of treatment.

\section{Discussion}

According to the study findings the great majority of the study population has vaginal infection. This finding is higher than that reported by many researchers such as Pant et al. (2008) who reported that the prevalence of RTIs counts less than half of their sample and more than half of the sample presented in Sullam et al. (2001) study. The study results was 
high, this could be referred to the sample size in the current study is less than the studies mentioned before.

In the current work there were infectious agents needed to be considered such as E.coli was reported less than one-third of infectious cases followed by Klebsilla less than one- quarter of the cases, staph.aureus less than one- fifth and streptococcus almost one- sixth. Alim et al. (2009) identified lower than our finding were report E.coli seven percent, staph.aureus ten percent, and Proteus two percent.

These study findings could be high due to low socio- economic standard as well as low nutritional status which play the important role in infection. Furthermore, unhygienic toileting practices, this agrees with Mumtaz et al. (2008) who reported that staphylococcus aureus was less than one- quarter.

On the other hand, the less frequent causative organism in this study was Candida, G. vaginalis, Proteus and Tricomoniasis respectively. This finding near to the results presented by Xueqian et al., (2007) who used the same diagnostic methods and reported G.vaginalis more than five percent of their sample, Candida and Trichomoniasis less than five percent respectively.

Moreover, closed to our study findings that reported by Khan et al. (2009) who notify G. vaginalis less than one- third, about five percent and less than five percent was Group B streptococcus and T. vaginalis respectively. These findings could be relevant to the strict religious and cultural believes which prohibits illegal sexual relationships.

The prevalence of Candida in this study agrees with the prevalence reported by Alim et al. (2009) and (Neerja et al., 2006) they reported that, Candida infection was more than ten percent of their samples and relevant that to pregnancy and increase in parity. While, higher than this study prevalence of candida reported in the study of Puri et al. (2003) who noted less than one third of their sample with candida.

Regarding the prevalence of G. vaginalis, the current study finding agrees with the finding of Alim et al. (2009) and Azaz et al. (2005) who reported that, the frequency of BV using Amsel's criteria was more than ten percent. On the other hand disagrees with Puri et al. (2003) who noted BV less than one third of their sample and Muvunyi et al. (2009) who noted BV less than one fifth of their sample. T. vaginalis and streptococci noted in the study closed to reported by Sullam et al. (2001). Our study finding also agrees with the findings reported 
by Puri, et al. (2003). On the other hand disagrees with Gavgani et al. (2008) who noted T. vaginalis less ten present of their sample.

Generally, the problem of vaginal infection rests on the bad health behaviors. The present study findings revealed unsatisfactory hygienic practices among the studied women. Based on collected data more than two third of infected women using public water cycle. The use of toilets present in public place without proper disinfected after the using of others put the women under the risk of infection (Gupte et al., 2009).

Most of infected women in this study wear daily perineal pad this findings was higher than findings reported by Kisa \& Taskin (2007) and Kisa \& Taskin (2010) they noted about two third of their sample use daily pad. The usage of daily perineal pad prevents perineal ventilation and increase risk for vaginal infection (Kisa \& Taskin, 2010).

Regarding changing of underwear, the majority of infected women didn't change underwear daily compared to the result reported by Karaer et al. (2005) and Kisa \& Taskin (2010) they noted that less than one- third of their sample didn't change underwear daily. Furthermore, almost two third of infected women didn't use cotton underwear whereas the majorities of them didn't use proper disinfected way for cotton underwear or cloth pad and about one- fifth didn't hang under wears in sun rays, all of this increase the risk for invasion of infections (Bahram et al., 2009). The most common unhygienic vaginal practice in this study was vaginal cleaning with water and soap, using finger. The present study also denoted that, about half of infected women didn't cut their nail frequently. Fingernails considered one of the areas commonly affected by fungal and bacterial infections which may be transfer it into vagina during vaginal washing (Sheary \& Dayan, 2005).

Regarding vaginal douching after intercourse, about one- third of infected women was perform vaginal douching after intercourse this finding similar to many researchers such as $\mathrm{Li}$ et al. (2010); Kisa \& Taskin (2010) and Leon et al. (2009) they reported also almost one- third of their sample perform vaginal douching after intercourse. Less than three- quarters of infected women introduce soapy water into the vagina during washing and put their fingers inside the vagina during washing.

In the present study, we found the most common reasons for douching was to prevent or treat symptoms of vaginitis as itching, undesirable odors and discharge. Also several women felt that menstrual blood was inherently dirty "bad blood" that needed to be removed from the vagina as well as douching after intercourse to remove the semen from the vagina, and to 
enhance sexual relationship this view also presented at Braunstein (2003) study. McClelland (2007) indicated that vaginal douching for hygienic reason was an important risk factor and doubled the risk of acquiring vaginitis.

In the present study, the great majority of infected women using sanitary pad during menstruation, one sixth using cloth towel and about one third using sanitary pad and/ or cloth towel. Comparing to Onal et al. (2010) less than half of their sample use hygienic pad, less than ten present use fabric, and more than one third use hygienic pad and /or fabric. Pant et al. (2008) reported that, two fifth use unworked clothes, and less than one third use washed clothes and sanitary pads. The rate of sanitary pad user reported by Singh (2006) extremely low than in our study this due to the report of low socio- economic status of their sample.

Menstrual hygienic practices are important to limit the risk for infections. One of these practices is regular changing of pads. The damp pad contaminated with the body's innate organisms and sweat from genitals remains in a warm and moist place for a long time they tend to multiply the organisms and can lead to vaginal infections (House et al., 2012). In our study more than half of infected women use cloth towel without changing it every $4 \mathrm{hr}$ and almost fifth of woman using sanitary pad without changing it every $6 \mathrm{hr}$ this result revealed the lack of knowledge about dealing with menstrual hygiene.

Taking a shower during menstruation is necessary to ensure genital and body hygiene. On the other hand, not taking a bath during the menstruation is a traditional practice in our culture due to bathing during that time is believed to weaken the woman's bones (House et al., 2012). In our work less than one- quarter of women didn't shower during menstruation, this findings lower than reported by Kisa \& Taskin (2010) and higher than reported by Li et al. (2010). These variations describe the difference in educational level between the results of studies.

According the study findings more than two -quarter of women wiping the genital area from back to front or mixing whereas about hundred present of the women wiping with bare hand. These results are agrees with findings reported by (Kisa \& Taskin, 2010). Our findings denoted the association between vaginal infections and wiping behaviors this finding agrees with many previous studies as Karaer et al. (2005); Karatay \& Ozvaris (2006) and Kisa \& Taskin (2007).

According to our study finding less than two fifth of infected women didn't dry after toileting, this result more than findings reported by Kisa \& Taskin (2010). On the other hand less than two third of infected woman dry after toileting and about ten present of them dry 
with toilet paper. This result disagrees with the result reported by Onal et al. (2010) who noted that the majorities of the sample used toilet paper for drying after toileting.

The greater majority of infected women perform hand washing after toileting with soap and water, while about five present wash with only water and less than one present didn't wash their hands in variance to Onal et al. (2010) who reported the greater majority wash hands each time after toileting, and less than four present didn't perform hand washing after toileting.

The current study denoted that the majority of infected women previously treated whereas more than one third of them didn't take prescribed medication with regimen. Unhygienic vaginal practices and treatment without examination or investigation to discover the type of microorganism that exists of course lead to one of two things: first, temporarily relieved the symptoms and then return that urge the woman to repeat the treatment from herself if feel symptoms of vaginitis. Second, they didn't complete treatment because the feeling of discomfort. Also this result could be relevant to low socio- economic standards which affect the ability of the women to buy the medication. This result in variance to Patel et al. (2003) who reported that, less than half had past use of medications while more than half didn't use it.

Finally, this study revealed that, prevalence of vaginal infection was significantly high, whereas the majority of infected women had unsatisfactory health behaviors. The results of this study agrees with Pant et al. (2008) who reported that, less than half of their sample, more than two fifth and more than one fifth in women having poor, fair and good personal hygiene.

\section{Conclusion:}

The married women attending PHC centers in Ismailia city has unsatisfactory level of health behaviors. There were high significant association between unsatisfactory health behaviors as personal hygiene, sexual hygiene, menstrual hygiene, vaginal hygienic practices and toileting practices and vaginal infection.

On the light of the results of the current study, the following recommendations are suggested:

Health educational program through different media to women for vaginal proper hygienic care and health behaviors that can be used to promote the prevention of vaginal infection for women throughout their lives was recommended. 


\section{References}

Alim, A.; Cetin, A. \& Yildiz, C. (2009): Evaluation of vaginal flora and susceptibility test of microorganisms in reproductive age women with or without vaginitis in primary care sittings. J. Cumhuritey Medical Journal; 31: 116- 21.

American Academy of Nurse practitioners (AANP) (2010): Health promotion, risk reduction and disease prevention. J. Journal of American Academy of nurse practitioners; 22: 57- 9.

American Social Health Association (ASHA) (2013): Vaginitis Menlo Research triangle Park. Available from asha, creating asexual health nation at: www.ashasexualhealth.org 11-102013, $10.00 \mathrm{pm}$

Azaz, S.; Chaudhry, A.; \& Kareem, F. (2005): Bacterial vaginosis in patients at MH Rawalpindi. J. Pakistan Armed Forces Medical Journal; 55(1):24-8.

Bahram, A.; Hamid, B. \& Zohre, T. (2009): Prevalence of bacterial vaginosis and impact of genital hygiene in non pregnant women in Zanjan, Iran. J. Oman Medical Journal; 24 (4): 288- 93.

Bradshaw, C. S; Morton, A. N.; Hocking, J.; Garland, S. M.; Morris; Moss, M. B.; Horvath, L. B.; Kuzevska, I.; \& Fairley, C. K. (2006): High recurrence rates of bacterial vaginosis over the course of 12 months after oral metronidazole therapy and factors associated with recurrence. J. The Journal of Infectious Diseases; 193(11): 1478- 86.

Braunstein, S. (2003): Cultural norms and behavior regarding vaginal lubrication during sex: implications for the acceptability of vaginal microbicides for the prevention of HIV/STIs. Critical issues in reproductive health, The Robert $\mathrm{H}$ program;12, quoted from Van de Wijgert, J. H. H.; Cornelisse, P. G. A.; Morrison, C.; Chitsungo, S.; Munjoma, M.; Rugpao, S.; Byamugisha, J.; Muchini, A.; Sriplienchan, S. \& Padian, N. S.(2002): Baseline associations between vaginal practices and vaginal infections

Gooch, J.W. (2011): Encyclopedia Dictionary of Polymers, $2^{\text {nd }}$ edition, Springer Science \& Business Media, LLC.

Gupte, P.; Patil, S. \& Pawaskar, R. (2009): Vulvovaginal hygiene and care. J. Indian Journal Sex Transm; 30:130-33.

House, S.; Mahon, T. \& Cavill, S. (2012): Menstrual hygiene - the basics. Module one; 22:41

Johnson, N.R. from Reece, E.A. \& Barbieri, R.l. (2010): Vaginitis and Vulvitis, Obstetrics and Gynecology, General Gynecology. The Essentials of Clinical Care, Part 3. Saunders: Elsevier; 1 (30): 293-4.

Karaer, A.; Boylu, M. \& Avsar, A.F. (2005): Vaginitis in Turkish women: symptoms, epidemiologic-microbiologic association. J. European Journal of Obstetrics Gynecology and Reproductive Biology ; 121:211-15

Karatay, G. \& Özvaris, S.B. (2006): Evaluation of applications regarding the genital hygiene of women living in barrel houses within a region existing a health center. J. Journal of Nursing School, University of Cumhuriyet, 10:7-U

Khan, I. \& Khan, U.A. (2004): A hospital based study of frequency of aerobic pathogens in vaginal infections. J. Rawal Med Coll.; 29(1):22-25. 
Khan, S. A.; Amir, F.; Altaf, S. \& Tanveer, R. (2009): Evaluation of Common Organisms Causing Vaginal Discharge. J. Journal of Ayub Medical College, Abbottabad, Pakistan; 21 (2) 90: 3 .

Kim, Y.H.; Kim, C.H.; Cho, M.K.; Na, J.H.; Song, T.B. \& Oh, J.S. (2006): Hydrogen peroxide-producing lactobacilli in the vaginal flora of pregnant women with preterm labor with intact membranes. J. International Journal of Gynaecology \& Obstetrics; 93:22-7.

Kisa, S. \& Taskin, L. (2007): Behavioral and socio demographic risk factors that affect vaginal infections among women aged between 15-49 who applied to $\mathrm{MCH} / \mathrm{FP}$ center in Ankara. Health and Society; 17 (1):69-84.

Kisa, S. \&Taskin, L. (2010): Behavioral risk factors that predispose women to vaginal infection in turkey. J. Pak Journal of Medical Sciences; 26 (4): 800- 4

Li, C.; Han, H.; Lee, J.; Lee, M.; Lee, Y. \& Kim, M. T. (2010): Knowledge, Behaviors and prevalence of reproductive tract infections: A descriptive study on rural women in Hunchun, China. Asian Nursing Research, Elsevier; 4 (3): 122- 9.

McClelland, R.S. (2007): Infection with Trichomonas Vaginalis increases the risk of HIV-1 acquisition. J. Infectious Diseases; 195(5):698-702.

Onal, A. E.; Onoglu, N.; Babaoglu, A.B.; Ozer, C. \& Gungor, G. (2011): Some hygiene behaviours and Genital infection complaints among 15-49 aged women in a Suburban area of Istanbul. J. Nobel Meoicus Journal; 7 (2): 96-100.

Pant B.; Singh, J. V.; Bhatnagar, M.; Garg, S. K.; Chopra, H. \& Bajpai, S. K. (2008): Social correlates in reproductive tract infections among married women in rural area of Meerut. J. Indian Journal of Community Medicine; 33 (1):52-3.

Sheary, B. \& Dayan, L. (2005): Recurrent vulvovaginal candidiasis. Aust Fam Physician; 34(3):147-50.

Singh, A.J. (2006): Place of menstruation in the reproductive lives of women of rural North India. J. Indian Journal of Community Medicine; 31:13. 


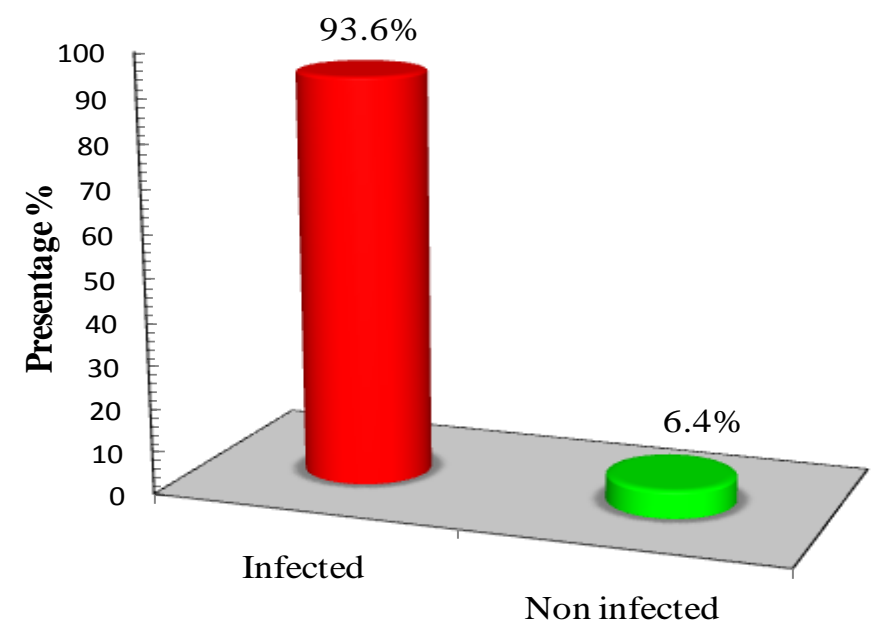

Figure (1) Distribution of the married women according to their vaginal infection $(n=360)$.

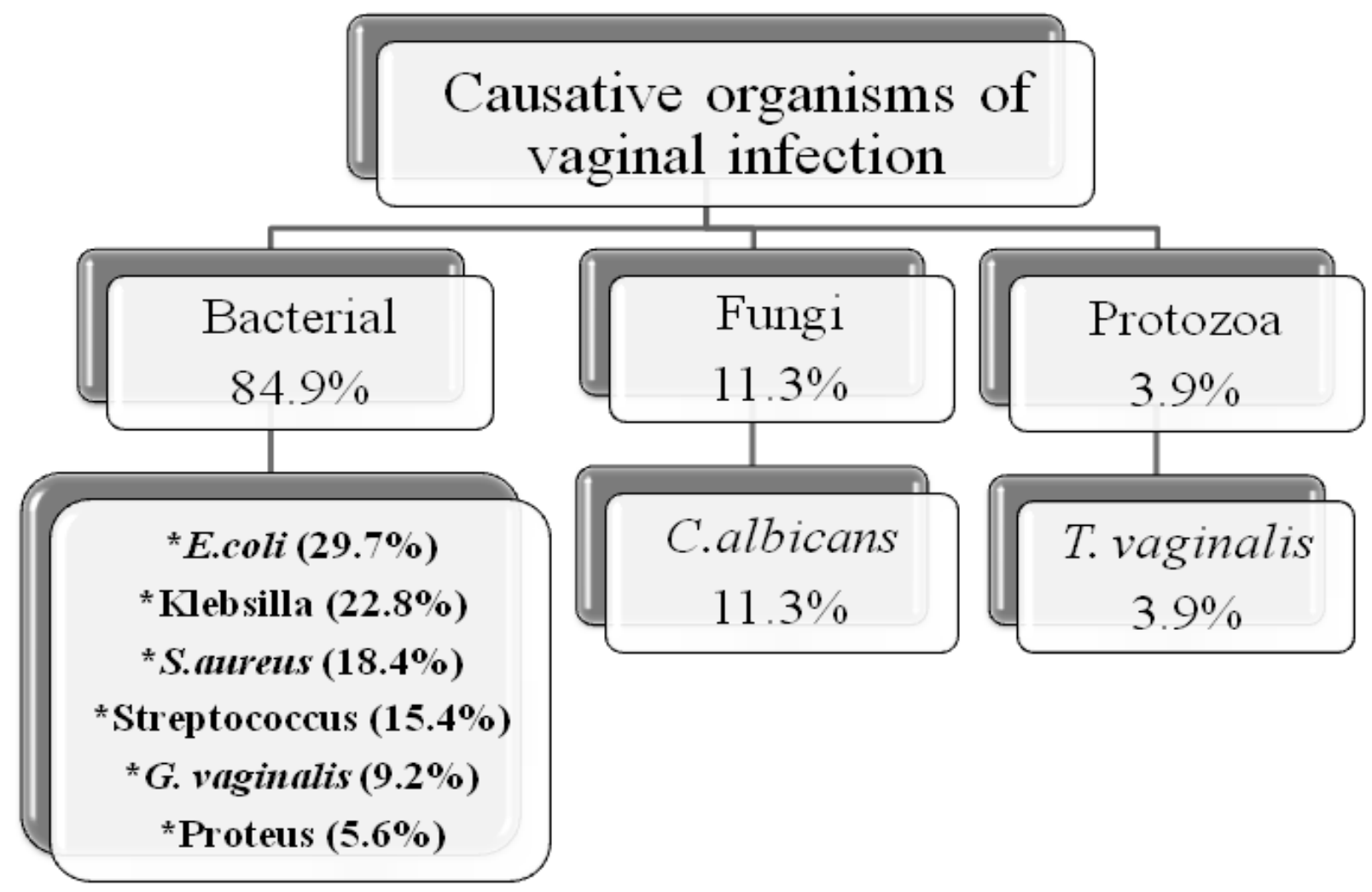

N.B. The sum of causative organism is more than $100 \%$ because the presence of mixed infection

Figure (2): The causative organisms of vaginal infection cases regarding microbiological analysis $(\mathrm{n}=337)$. 
Table (1): Distribution of the infected women according to their personal hygiene $(n=337)$

\begin{tabular}{|c|c|c|c|c|c|c|}
\hline \multirow{2}{*}{ Personal hygienic practices } & \multicolumn{2}{|c|}{ Yes } & \multicolumn{2}{|c|}{ No } & \multirow{2}{*}{$\mathbf{X}^{2}$} & \multirow{2}{*}{$P$ value } \\
\hline & No. & $\%$ & No. & $\%$ & & \\
\hline Didn't use public water cycle (WC) & 110 & 32.6 & 227 & 67.4 & 40.620 & $0.000 *$ \\
\hline Didn't use Daily perineal pad & 39 & 10.8 & 298 & 89.2 & 199.053 & $0.000^{*}$ \\
\hline Changing underwear daily & 73 & 21.7 & 264 & 78.3 & 110.531 & $0.000^{*}$ \\
\hline Use cotton underwear & 127 & 37.7 & 210 & 62.3 & 20.442 & $0.000^{*}$ \\
\hline Boil underwear and pads & 40 & 11.9 & 297 & 88.1 & 195.991 & $0.000 *$ \\
\hline Hang under wear in sun rays & 268 & 79.5 & 69 & 20.5 & 117.510 & $0.000 * *$ \\
\hline Cut Nail frequently & 164 & 48.7 & 173 & 51.3 & 0.240 & 0.624 \\
\hline Total & 59 & 17.5 & 278 & 82.5 & 142.318 & $0.000^{*}$ \\
\hline
\end{tabular}

$\left(X^{2}\right)=$ Chi square significance test

$(*)=$ Statistical significance between mal practices and vaginal infection at $p<0.05$

(**) =Statistical significance between performance and vaginal infection at $p<0.05$

Table (2): Distribution of the infected women according to their sexual unhygienic practices

\begin{tabular}{|c|c|c|c|c|c|c|}
\hline \multirow{2}{*}{ Sexual unhygienic practices } & \multicolumn{2}{|c|}{ Yes } & \multicolumn{2}{|c|}{ No } & \multirow{2}{*}{$\mathbf{X}^{2}$} & \multirow{2}{*}{$P$ value } \\
\hline & No. & $\%$ & No. & $\%$ & & \\
\hline Douching after intercourse $(n=337)$ & 98 & 29.1 & 239 & 70.9 & 58.994 & $0.000 * *$ \\
\hline $\begin{array}{l}\text { Husband use of lubricant before } \\
\text { intercourse }(\mathrm{n}=337)\end{array}$ & 37 & 11.0 & 300 & 89.0 & 205.249 & $0.000 * *$ \\
\hline Intercourse during infection $(\mathrm{n}=332)$ & 290 & 87.3 & 42 & 12.7 & 185.253 & $0.000 *$ \\
\hline Intercourse during menstruation $(\mathrm{n}=337)$ & 11 & 3.3 & 326 & 96.7 & 294.436 & $0.000 *$ \\
\hline Use of condom during infection $(n=336)$ & 1 & 0.3 & 335 & 99.7 & 332.012 & 0.318 \\
\hline Total & 221 & 65.6 & 116 & 34.4 & 32.715 & $0.000 *$ \\
\hline
\end{tabular}

$\left(X^{2}\right)=$ Chi square significance test

$(*)=$ Statistical significance between mal practices and vaginal infection at $p<0.05$

$(* *)=$ Statistical significance between performance and vaginal infection at $p<0.05$ 
Table (3): Distribution of the infected women according to their vaginal unhygienic practice $(n=337)$

\begin{tabular}{|l|c|c|c|c|c|c||}
\hline \multirow{2}{*}{ Vaginal unhygienic practices } & \multicolumn{2}{|c|}{ Yes } & \multicolumn{2}{|c|}{ No } & \multirow{2}{*}{$\mathbf{X}^{2}$} & \multirow{2}{*}{ P value } \\
\cline { 2 - 6 } & No. & $\boldsymbol{\%}$ & No. & $\boldsymbol{\%}$ & & \\
\hline Frequent vaginal douching & 202 & 59.9 & 135 & 40.1 & 13.320 & $0.000^{*}$ \\
\hline Douching with soapy water & 238 & 70.6 & 99 & 29.4 & 57.332 & $0.000^{*}$ \\
\hline Use fingers to clean the vagina & 233 & 69.1 & 104 & 30.9 & 12.813 & $0.000^{*}$ \\
\hline Douching in sitz bath & 63 & 31.0 & 139 & 69.0 & 30.119 & $0.000^{*}$ \\
\hline Total & 96 & 28.5 & 241 & 71.5 & 62.389 & $0.000^{*}$ \\
\hline
\end{tabular}

$\left(X^{2}\right)=$ Chi square significance test

$(*)=$ Statistical significance at $p<0.05$

Table (4): Distribution of the infected women according to their menstrual hygiene $(n=337)$

\begin{tabular}{|c|c|c|c|c|c|c|}
\hline \multirow{2}{*}{ Menstrual hygiene } & \multicolumn{2}{|c|}{ Yes } & \multicolumn{2}{|c|}{ No } & \multirow{2}{*}{$\mathrm{X}^{2}$} & \multirow{2}{*}{$P$ value } \\
\hline & No. & $\%$ & No. & $\%$ & & \\
\hline Use of sanitary pad & 284 & 84.3 & 53 & 15.7 & \multirow{2}{*}{158.341} & \multirow{2}{*}{$0.000^{*}$} \\
\hline Use of towel cloth & 126 & 37.5 & 284 & 84.3 & & \\
\hline Change sanitary pad / 6 hrs & 53 & 18.7 & 231 & 81.3 & 158.341 & $0.000^{*}$ \\
\hline Change towel cloth / 2:4 hrs & 40 & 40.8 & 58 & 59.2 & 3.306 & 0.069 \\
\hline Shower during menstruation & 250 & 74.2 & 87 & 25.8 & 78.840 & $0.000 *$ \\
\hline Total & 41 & 12.2 & 296 & 87.8 & 192.953 & $0.000 *$ \\
\hline
\end{tabular}

$\left(X^{2}\right)=$ Chi square significance test

$(*)=$ Statistical significance at $p<0.05$ 
Table (5): Distribution of the infected women according to their toileting practices $(n=337)$

\begin{tabular}{|c|c|c|c|c|c|c|}
\hline \multirow{2}{*}{ Toileting practice } & \multicolumn{2}{|c|}{ Yes } & \multicolumn{2}{|c|}{ No } & \multirow{2}{*}{$\mathbf{X}^{2}$} & \multirow{2}{*}{$\begin{array}{c}\mathbf{P} \\
\text { value }\end{array}$} \\
\hline & No. & $\%$ & No. & $\%$ & & \\
\hline $\begin{array}{l}\text { Bathing by using the } \\
\text { ground toilet }\end{array}$ & 136 & 40.4 & 201 & 59.6 & 12.537 & $0.000 *$ \\
\hline $\begin{array}{l}\text { Bathing by using stool } \\
\text { toilet }\end{array}$ & 201 & 59.6 & 136 & 40.4 & & \\
\hline $\begin{array}{l}\text { Wiping from front to back } \\
\text { after toileting }\end{array}$ & 109 & 32.3 & 228 & 67.7 & 42.021 & $0.000 *$ \\
\hline Wiping by bare hand & 337 & 100 & 0 & 0.00 & --- & --- \\
\hline Drying after toileting & 209 & 62.0 & 128 & 38.0 & 19.469 & $0.000 *$ \\
\hline Dry with toilet paper & 32 & 9.5 & 177 & 52.5 & 128.138 & $0.000 *$ \\
\hline $\begin{array}{l}\text { Disinfect cloth towel after } \\
\text { each drying }\end{array}$ & 42 & 17.6 & 197 & 82.4 & 100.523 & $0.000 *$ \\
\hline $\begin{array}{l}\text { Hand washing with soap } \\
\& \text { water }\end{array}$ & 20 & 5.9 & 317 & 94.1 & 544.350 & $0.000 *$ \\
\hline Total & 115 & 34.1 & 222 & 65.9 & 33.716 & $0.000 *$ \\
\hline
\end{tabular}

$\left(X^{2}\right)=$ Chi square significance test

$(*)=$ Statistical significance at $p<0.05$

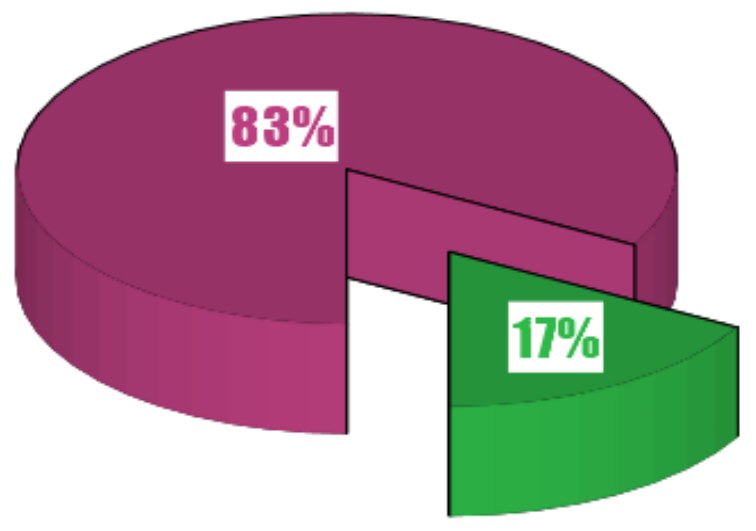

Figure (3): Satisfaction of health behaviors of infected women $(n=337)$. 
Table (6): Relationship between vaginal infection and compliance pattern to previous treatment variables

\begin{tabular}{|c|c|c|c|c|}
\hline \multirow[t]{2}{*}{ Compliance to the medication } & \multicolumn{2}{|c|}{$\begin{array}{c}\text { Infected cases } \\
(\mathrm{n}=337)\end{array}$} & \multirow[t]{2}{*}{$\mathbf{X}^{2}$} & \multirow[t]{2}{*}{$P$ value } \\
\hline & No. & $(\%)$ & & \\
\hline \multicolumn{5}{|l|}{ Previously treated $(\mathrm{n}=\mathbf{3 3 7})$} \\
\hline Yes & 281 & 83.4 & \multirow{2}{*}{144.929} & \multirow{2}{*}{$0.000^{*}$} \\
\hline No & 56 & 16.6 & & \\
\hline \multicolumn{3}{|l|}{ Use the prescribed medication $(\mathrm{n}=281)$} & \multirow{3}{*}{17.940} & \multirow{3}{*}{$0.030^{*}$} \\
\hline Yes & 176 & 63.1 & & \\
\hline No & 105 & 36.9 & & \\
\hline \multicolumn{3}{|l|}{$\begin{array}{l}\text { Use Other modalities without medical } \\
\text { advice }(\mathrm{n}=93)\end{array}$} & \multirow{3}{*}{14.129} & \multirow{3}{*}{$0.001 *$} \\
\hline Medication without medical prescription & 55 & 16.3 & & \\
\hline Home remedies & 52 & 15.4 & & \\
\hline \multicolumn{5}{|l|}{ Person who advice } \\
\hline Relatives & 74 & 78.7 & & \\
\hline Pharmacist & 17 & 18.1 & 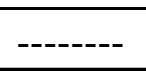 & $\begin{array}{c}---- \\
\end{array}$ \\
\hline Nurse & 10 & 10.6 & & \\
\hline \multicolumn{3}{|l|}{ Treatment prescribed for spouse $(\mathrm{n}=\mathbf{2 8 1})$} & \multirow{3}{*}{66.794} & \multirow{3}{*}{$0.000^{*}$} \\
\hline Yes & 72 & 25.6 & & \\
\hline No & 209 & 74.4 & & \\
\hline \multicolumn{3}{|l|}{$\begin{array}{l}\text { Spouse use the prescribed medication } \\
(\mathrm{n}=72)\end{array}$} & \multirow{3}{*}{10.889} & \multirow{3}{*}{$0.001^{*}$} \\
\hline Yes & 50 & 69.4 & & \\
\hline No & 22 & 30.6 & & \\
\hline
\end{tabular}

$\left(X^{2}\right)=$ Chi square significance test

$\left(^{*}\right)=$ Statistical significance at $p<0.05$

The total number of advisement not equal 100\% because the of double sources of advisements 
السلوكيات الصحية للعدوى المهبلية بين النساء المتزوجات في مدينة الإسماعيلية

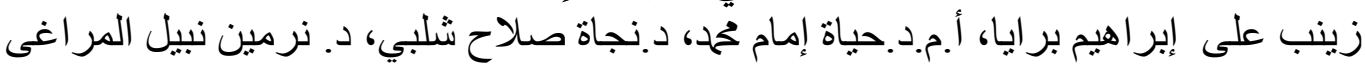
بكالوريوس تمريض - جامعة قناة السويس، أستاذ مساعد صحة الأم وحديثي الو لادة- كلية التمريض-

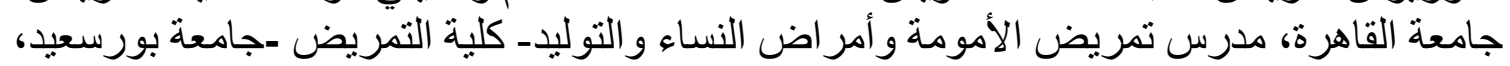

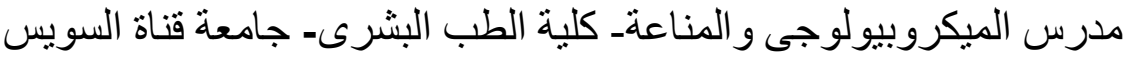

\section{الخلاصة}

إن الالتهابات المهبلية مشكلة صحية كبيرة ينتج عنها العديد من المشكلات النفسية والجسدية للسيدة خلال مر احل عمر ها المختلفة.وجاء الهذف من هذه الدر اسة لتقييم السلوكيات الصحية للعدوى المهبلية بين النساء المتزوجات بمدينة الإسماعيلية، وتضمنت هذه الدراسة الوصفية على عينة مكونة من جس سيدة بمعايير اختيار محددة من عيادات النساء وتنظيم الأسرة في المر اكز والوحدات الصحية الحضرية والريفية المختارة طبقاً للتوزيع الجغر افي و الكثافة السكانية، وتم جمع البيانات باستخدام أداتين الأولى مقابلة شخصية مع النساء لتقييم سلوكياتهن الصحية والعو امل المسبية للعدوى و الثانية اختبار ات ميكروبيولوجية لتحديد نوع البكتريا المسببة للعدوى .وقد أظهرت النتائج ان 7. ب9\% من النساء مصابات بعدوى مهبلية.وأوضحت النتائج أيضا تكر ار العدوى في ا. •^\% من النساء المصابات. أما فيما يتعلق بالسلوكيات الصحية للنساء فوجد أن

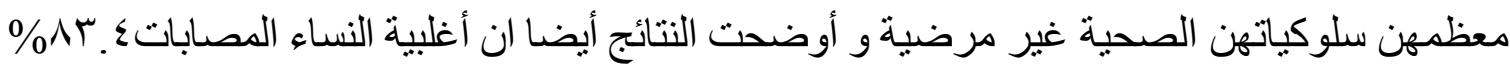
سبق علاجهن من الالتهابات المهبلية، من بينهن ه.ب\%\% لم يلتزمن بقو اعد العلاج المنصوص عليها. و استخلصت نتائج الدر اسة على أن معظم النساء مصابات بعدوى مهبلية سلوكياتهن الصحية غير مرضية ولذلك أوصت الدر اسة بتنظيم برنامج صحية تعليمية من خلال وسائل الإعلام المختلفة لتوعية النساء بمبادئ الرعاية الصحية و الصحة المهبلية من خلال تعليمهن السلوكيات الصحية التي تعزز الوقاية من العدوى المهبلية لايهن في جميع مر احل حياتهن المختلفة. الكلمات الدالة: الإلتهابات المهبلية، السلوكيـات والممارسات الصحية، النساء المتزوجات، سن الإنجاب. 